\title{
Isolation and Characterization of Actin from Mackerel Dark Muscle
}

\author{
Shugo Watabe*1, Yasuo ItoH*2, and Kanehisa Hashimoto*1 \\ (Accepted July 26, 1982)
}

\begin{abstract}
G-Actin was extracted from the acetone powder of the dark muscle of mackerel Pneumatophorus japonicus japonicus, and purified by a method which essentially consisted of polymerization in $0.1 \mathrm{M} \mathrm{KCl}$ containing $0.1 \mathrm{~mm} \mathrm{MgCl}$, treatment with $0.6 \mathrm{M} \mathrm{KCl}$, and Sephadex G-200 gel filtration.

Sedimentation constant $\left(\mathrm{s}_{20, \mathrm{~m}}^{\mathrm{0}}\right)$ of the dark muscle actin was $2.9 \mathrm{~S}$. The molecular weight was determined to be 42,000 by SDS-gel electrophoresis. The intrinsic viscosity [ $\eta]$ was $5.3 \mathrm{~d} l / \mathrm{g}$ in F-form. It featured higher glutamic acid, aspartic acid and alanine contents, and lower histidine and tryptophan contents. One mole of 3-methylhistidine per mole actin was detected.

The above physicochemical properties were essentially the same as those of actins from various sources, including mackerel ordinary muscle.
\end{abstract}

Most fishes have two types of muscle, the white ordinary and the dark muscle running under the lateral line. It has generally been accepted that the dark muscle is used for the slow and continuous swimming of fish, and the ordinary muscle for a burst. ${ }^{1,2)}$

In this connection, myofibrillar $\mathrm{Mg}^{2+}$-ATPase activity of the piscine ordinary muscle has been reported to be higher than that of the dark muscle, ${ }^{8-5)}$ the fact that is remniscent of the relationship between mammalian fast and slow muscles. ${ }^{\text {) }}$ If the dark muscle is used for continuous swimming as described above, this work could be best achieved by a slow muscle.

As we have already reported, ${ }^{72}$ mackerel ordinary and dark muscle myosins have three and two kinds of light chain, respectively, as do the fast and slow muscle myosins of rabbit. This interrelationship between the four myosins does not hold as far as $\mathrm{Ca}^{2+}$-ATPase activity is concerned; the dark muscle myosin shows a higher activity than the ordianry muscle myosin in fish, ${ }^{7,8}$ ) whereas the slow muscle myosin generally is lower in $\mathrm{Ca}^{2+}$. ATPase activity than the fast muscle myosin. ${ }^{8, \theta}$

This discrepancy aroused us to characterize and compare actins from both muscles of mackerel, and the present study was undertaken.

\section{Materials and Methods}

\section{Material}

Live specimens of the mackerel Pneumatophorus japonicus japonicus ( $300 \mathrm{~g}$, average body weight) were decapitated immediately after catch, transported to our laboratory in dry ice, and kept frozen at $-80^{\circ} \mathrm{C}$ until used.

\section{Isolation of Actin}

The dark and ordinary muscles were excised from the frozen mackerel specimens, and minced. The minced muscle was washed with $0.4 \% \mathrm{NaHCO}_{3}$ and cold water, and derived into acetone powder by the procedure described before. ${ }^{10)}$ Elimination of myosin from the mince was omitted this time. ${ }^{11}$

To the acetone powder of each muscle was added 20 volumes of $2 \mathrm{mM}$ Tris- $\mathrm{HCl}(\mathrm{pH} 8.0)$ containing $0.2 \mathrm{mM}$ ATP, $0.5 \mathrm{~mm}$ 2-mercaptoethanol and $0.2 \mathrm{mM} \mathrm{CaCl}_{2}$ (buffer A). ${ }^{12)}$ The mixture was stirred at $0^{\circ} \mathrm{C}$ for $30 \mathrm{~min}$ and filtered. Three molar $\mathrm{KCl}$ and $0.1 \mathrm{M} \mathrm{MgCl}_{2}$ were added to the filtrate at the final concentrations of $0.1 \mathrm{M}$ and $1 \mathrm{~mm}$, respectively. The mixture was allowed to stand at $20^{\circ} \mathrm{C}$ for $30-40 \mathrm{~min}$, until G-actin was polymerized into F-actin completely, with the viscosity reaching the maximum plateau. In the case of the dark muscle, the F-actin solution thus obtained was divided into two portions.

One portion was centrifuged at $70,000 \times \mathrm{g}$ for $2 \mathrm{~h}$, and the resulting F-actin pellet was depolymerized by exhaustive dialysis against buffer $\mathrm{A}$. The depolymerized actin was subjected to Sephadex G-200 gel filtration. ${ }^{13)}$ Undenatured G-actin fraction was collected and analyzed.

*1 Laboratory of Marine Biochemistry, Faculty of Agriculture, The University of Tokyo, Bunkyo, Tokyo 113, Japan (渡部終五・橋本周久: 東京大学農学部水産化学研究室).

*2 Present address： Marine Ecology Research Institute, Onjuku, Isumi, Chiba 299-51, Japan （伊藤康男： 東京大学農学部, 現所属 (財) 海洋生物環境研究所). 
To another portion was added $3 \mathrm{M} \mathrm{KCl}$ to a final concentration of $0.6 \mathrm{M} .{ }^{12)}$ The mixture was allowed to stand for $1 \mathrm{~h}$, and centrifuged at $70,000 \times \mathrm{g}$ for $2 \mathrm{~h}$. The pellet was dialyzed against buffer $\mathrm{A}$ and analyzed.

The latter procedures, which were proved better than the former as described below, were applied to the ordinary muscle of mackerel, and the actin preparation obtained was analyzed.

\section{Analytical Methods}

Sedimentation analyses were carried out at $60,000 \mathrm{rpm}$ and $10^{\circ} \mathrm{C}$ with a Hitachi UCA-1A analytical ultracentrifuge. Sedimentation coefficients calculated by Svedberg's formula were plotted against protein concentrations, in order to extrapolate sedimentation constant. A partial specific volume of rabbit actin, $0.732 \mathrm{~m} l / \mathrm{g}^{14}$ ) was used in calculation.

Sodium dodecyl sulfate (SDS)-gel electrophoresis was performed in $10 \%$ polyacrylamide gels containing $0.1 \%$ SDS. ${ }^{16)}$ In molecular weight estimation, protein markers (Schwartzmann) were used.

Viscosity was measured with Ostwald type viscometers having flow times of $60-120 \mathrm{~s}$ for water at $20 \pm 0.05^{\circ} \mathrm{C}$. In a given viscometer, a solution of unpolymerized actin (G-actin) was placed, and to it was added $0.1 \mathrm{M} \mathrm{KCl}$ and $1 \mathrm{~mm} \mathrm{MgCl}_{2}$ to convert G-into F-actin, and the flow time recorded as usual.

For amino acid analysis, both mackerel actins were hydrolyzed with $6 \mathrm{~N} \mathrm{HCl}$ at $110^{\circ} \mathrm{C}$ for 24,48 , and $78 \mathrm{~h}$ in sealed evacuated tubes and analyzed for amino acids with a Hitachi KLA-5 amino acid analyzer. Half cystine was determined after oxidation with performic acid, ${ }^{18)}$ and tryptophan after hydrolysis with $p$-toluene sulfonic acid. ${ }^{17)}$ 3-Methylhistidine was assayed by the method of JoHNSON et al. ${ }^{18)}$

Thermal denaturation curve was determined taking solubility as a parameter according to TAGUCHI et al. ${ }^{19)}$ The protein was dissolved in buffer A $(1 \mathrm{mg} / \mathrm{m} l)$, heated at various temperatures for $10 \mathrm{~min}$ and centrifuged at $10,000 \times \mathrm{g}$ for $20 \mathrm{~min}$. Protein concentrations of the supernatants were determined as described below. Results are expressed by percentage to the initial protein concentration.

Protein concentration was measured by the biuret method. ${ }^{20)}$ Refer to the preceding paper ${ }^{7)}$ for further details of those methods.

\section{Results and Discussion}

\section{Isolation of Actins}

Actin was extracted with 20 volumes of buffer $\mathrm{A}$ from the acetone powder of the dark muscle. The crude actin was polymerized in $0.1 \mathrm{M} \mathrm{KCl}$ and $1 \mathrm{~mm}$ $\mathrm{MgCl}_{2}$, but with a relatively small increase in viscosity (Fig. 1). Then the crude G-actin was purified by a polymerization-depolymerization procedure, followed by gel filtration on a Sephadex G-200 column $(2.5 \times 90 \mathrm{~cm})$ equilibrated with buffer $A$ (Fig. 2). Five-ml fractions were collected and checked by electrophoresis and polymerizability in $0.1 \mathrm{M} \mathrm{KCl}$ and $1 \mathrm{mM} \mathrm{MgCl}_{2}$. The fractions indicated by the shaded area were considered as native $\mathrm{G}$-actin and combined. The specific viscosity was increased up to 0.55 at a protein concentration of $1 \mathrm{mg} / \mathrm{ml}$. This value is much higher than that of the once-polymerized preparation, about $\mathbf{0 . 3}$, as shown in Fig. 1. The G-actin thus purified was, however, contaminated with some tropomyosin (Fig. 2)

Then one step was introduced to eliminate tropomyosin: to the polymerized actin was added $3 \mathrm{M}$ $\mathrm{KCl}$ up to a final concentration of $0.6 \mathrm{M}$, and the mixture allowed to stand for $1 \mathrm{~h} .{ }^{12)}$ The mixture was centrifuged at $70,000 \times \mathrm{g}$ for $2 \mathrm{~h}$. The Gactin pellet obtained was demonstrated to be homogeneous in SDS-gel electrophoretic pattern (data not shown). The G-actin exhibited Curve b (Fig. 3) when polymerized by aid of neutral salts. The G-actin was further purified by Sephadex G200 gel filtration, resulting in a highly pure preparation with a specific viscosity, 0.55 . The yield was

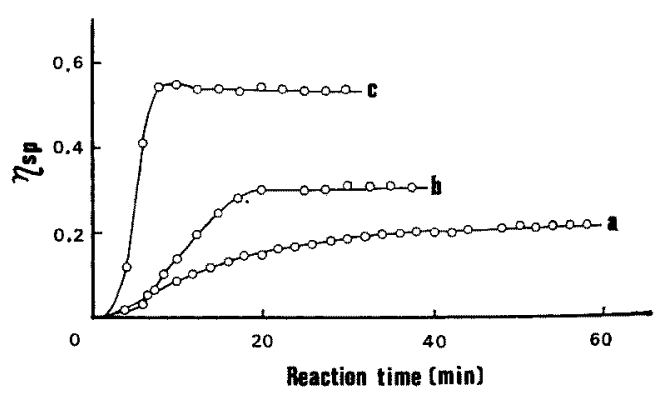

Fig. 1. Polymerization of crude G-actin in mackerel dark muscle (a), of the G-actin which was partially purified by a polymerization-depolymerization procedure (b), and of the G-actin further purified by Sephadex G-200 gel filtration (c). Conditions of polymerization: $0.1 \mathrm{M} \mathrm{KCl}$ and $1 \mathrm{mM} \mathrm{MgCl}_{2}, 1 \mathrm{mg}$ protein $/ \mathrm{m} l$ in buffer $\mathrm{A}, 20^{\circ} \mathrm{C}$. 

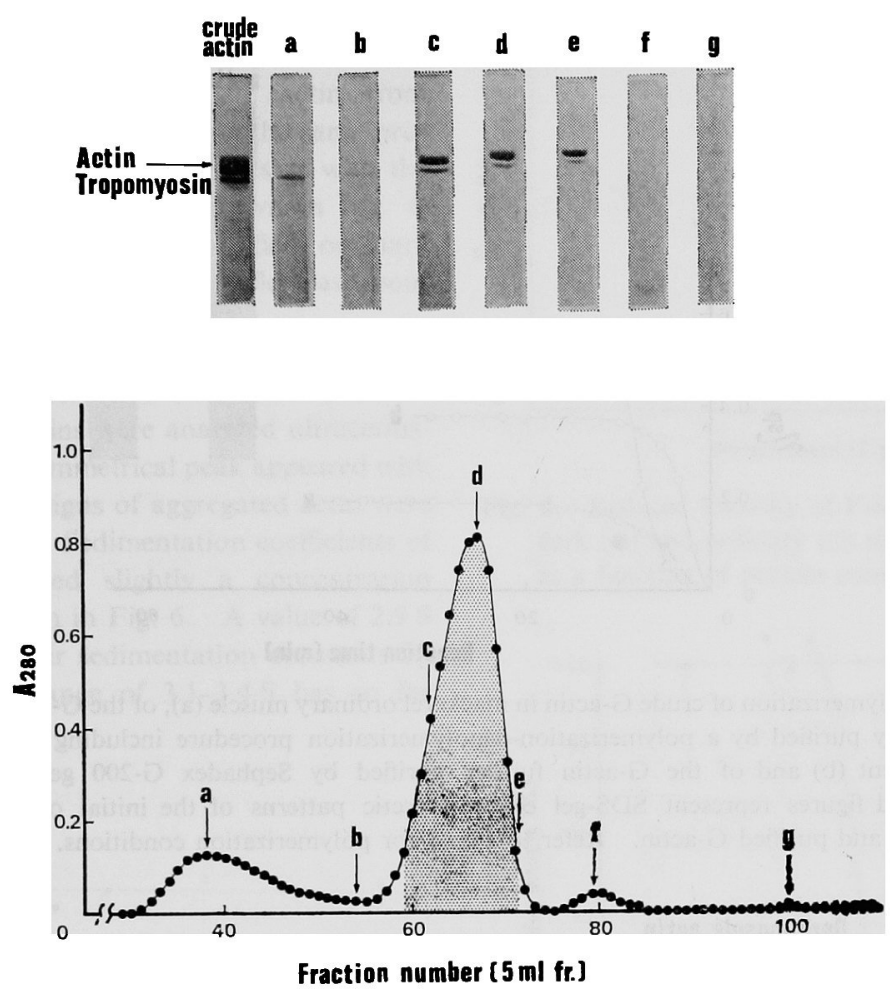

Fig. 2. Sephadex G-200 gel filtration of mackerel dark muscle G-actin which was partially purified by a polymerization-depolymerization procedure. Inserted figures represent SDS-gel electrophoretic patterns of the fractions indicated by arrow. $10 \%$ gel.

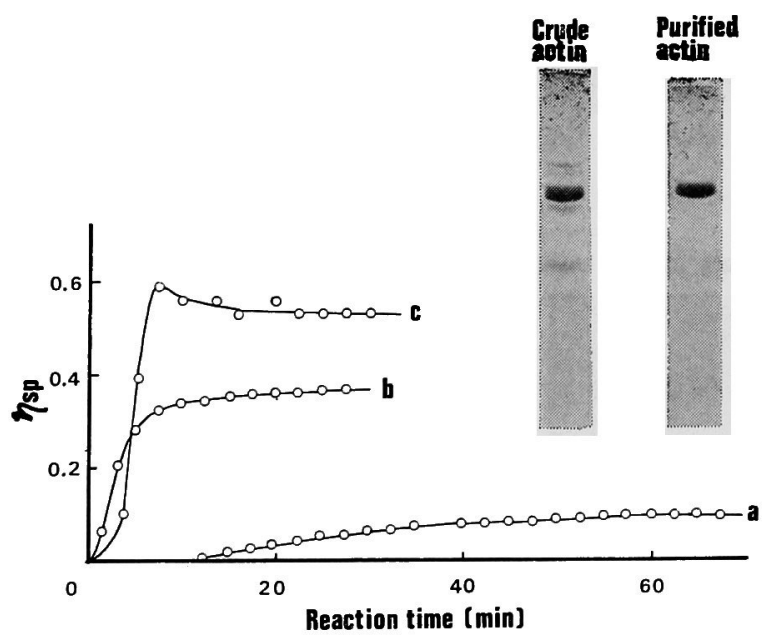

Fig. 3. Polymerization of crude G-actin in mackerel dark muscle (a), of the G-actin which was partially purified by a polymerization-depolymerization procedure including the $0.6 \mathrm{M} \mathrm{KCl}$ treatment (b), and of the G-actin further purified by Sephadex G-200 gel filtration (c). Inserted figures represent SDS-gel electrophoretic patterns of the initial dark muscle extract and purified G-actin. Refer to Fig. 1 for polymerization conditions. 


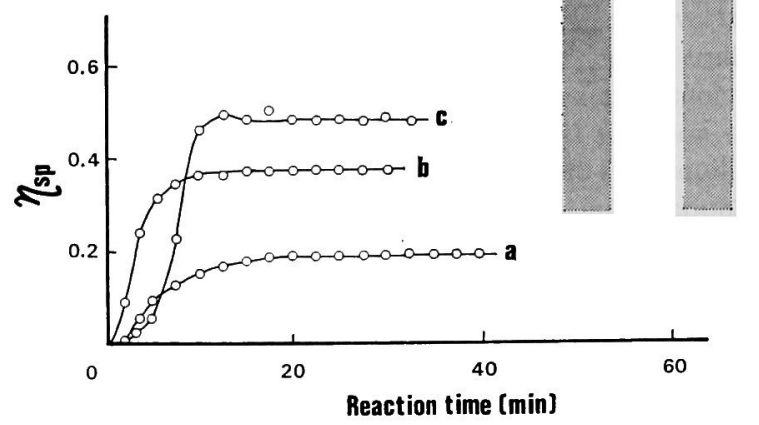

Fig. 4. Polymerization of crude G-actin in mackerel ordinary muscle (a), of the G-actin which was partially purified by a polymerization-depolymerization procedure including the $0.6 \mathrm{M} \mathrm{KCl}$ treatment (b) and of the G-actin further purified by Sephadex G-200 gel filtration (c). Inserted figures represent SDS-gel electrophoretic patterns of the initial ordinary muscle extract and purified G-actin. Refer to Fig. 1 for polymerization conditions.

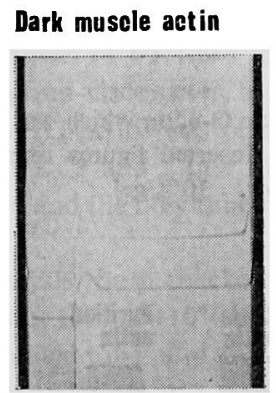

$20 \mathrm{~min}$

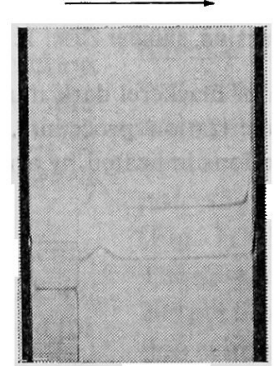

$40 \mathrm{~min}$

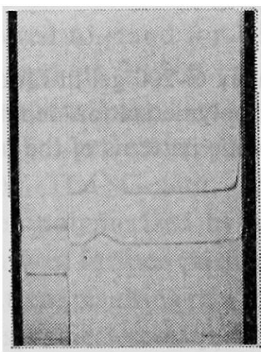

$60 \mathrm{~min}$

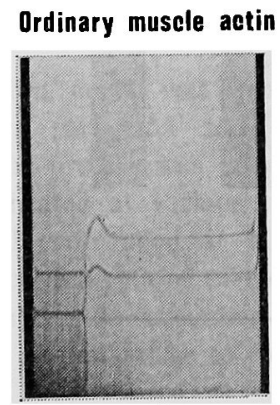

$20 \mathrm{~min}$

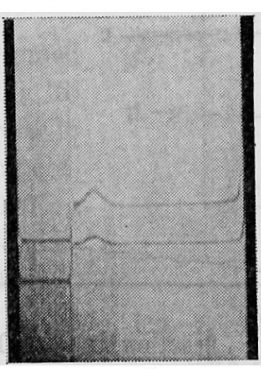

$40 \mathrm{~min}$

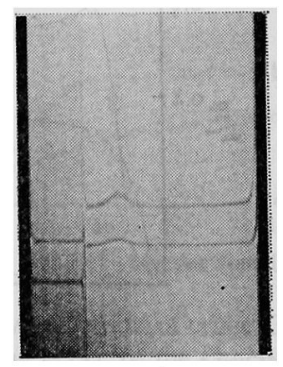

$60 \mathrm{~min}$

Fig. 5. Sedimentation patterns of G-actins from mackerel dark and ordinary muscles at $10^{\circ} \mathrm{C}$ in buffer A. Protein concentrations were 3.30 (upper) and 1.52 (lower) $\mathrm{mg} / \mathrm{m} l$ in the case of dark muscle actin, and 2.46 (upper) and 1.23 (lower) $\mathrm{mg} / \mathrm{m} l$ in the case of ordinary muscle actin. Photographs were taken at 20,40, and 60 min after reaching the top speed, $60,000 \mathrm{rpm}$. 
approximately $35 \mathrm{mg}$ from the starting material $100 \mathrm{~g}$.

Attempts were made to isolate actin from mackerel ordinary muscle, applying the same procedures. Essentially the same results as with the dark muscle were obtained as shown in Fig. 4. The specific viscosity of the purified ordinary muscle actin was near 0.5 . The yield was about $45 \mathrm{mg}$ from $100 \mathrm{~g}$ muscle.

\section{Physicochemical Properties}

Both mackerel actins were analyzed ultracentrifugally. A single symmetrical peak appeared with either actin and no signs of aggregated actin were recognized (Fig. 5). Sedimentation eoefficients of either actin exhibited slightly a concentration dependence as shown in Fig. 6. A value of $2.9 \mathrm{~S}$ was obtained as their sedimentation constants by extrapolation. A range of $3.1-3.4 \mathrm{~S}$ has so far

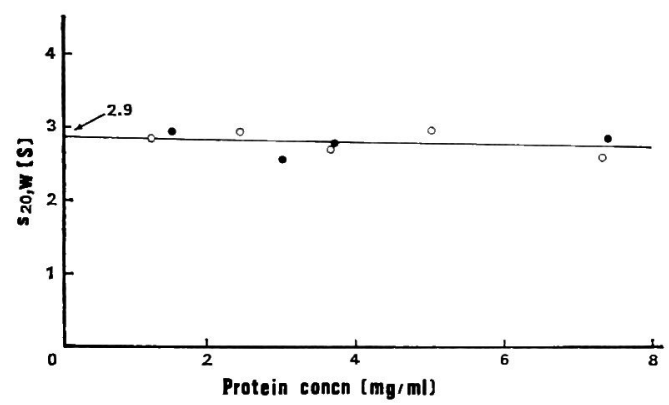

Fig. 6. Concentration dependence of sedimentation coefficient of G-actin from mackerel dark (৩) and ordianry (O) muscles in buffer A.

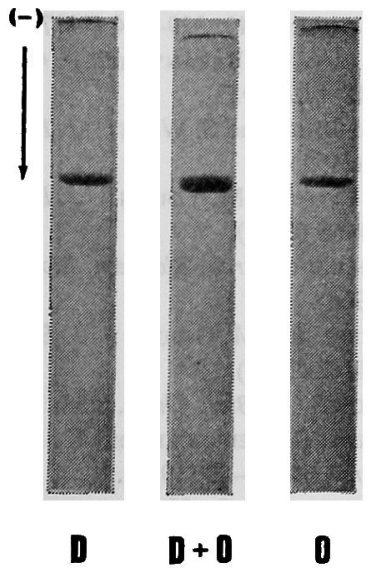

Fig. 7. SDS-gel electrophoretic patterns of actin from mackerel dark (D) and ordinary (O) muscles, and of their mixture $(D+O)$.

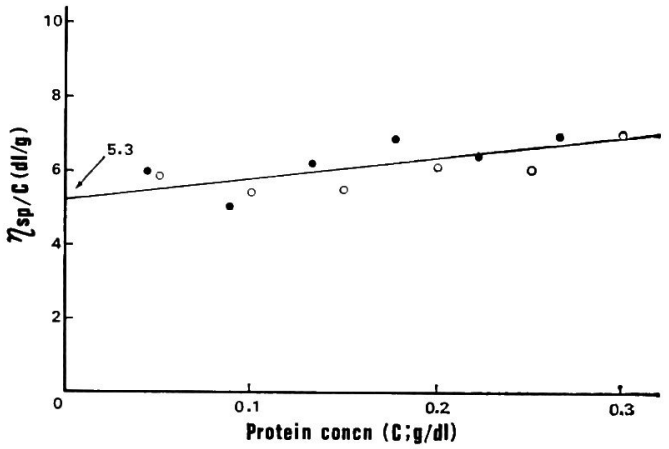

Fig. 8. Reduced viscosity of F-actin from mackerel dark (๑) and ordinary $(O)$ muscles in buffer A, as a function of protein concentration.

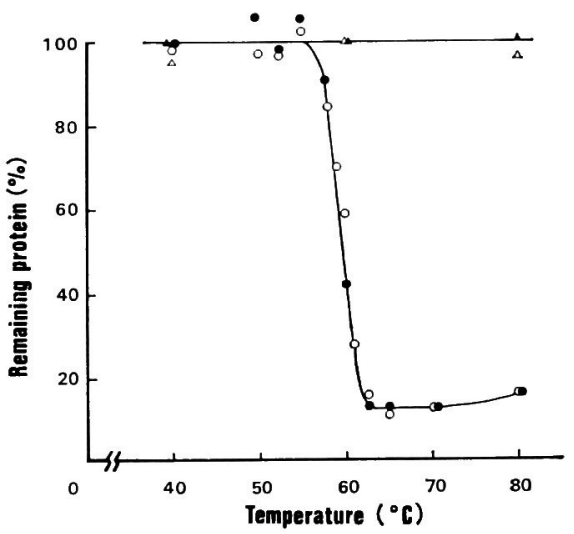

Fig. 9. Thermal denaturation curves of mackerel dark and ordinary muscle actins in buffer $\mathbf{A}$. Samples used were dark muscle G-actin ( $\Delta$ ) and F-actin $(\bullet)$, and ordinary muscle G-actin $(\Delta)$ and F-actin (O). Protein concentration: $1 \mathrm{mg} / \mathrm{m} l$.

been reported for those of $\mathrm{G}$-actins from various sources. ${ }^{10,21-24)}$

As shown in Fig. 7, SDS-gel electrophoretic analyses of both mackerel actins revealed the identity of their mobilities and hence of their molecular weights $(42,000)$, in agreement with other actins. ${ }^{11-19,25-29)}$

In Fig. 8 is given the reduced viscosity $\left(\eta_{\mathrm{Bp}} / C\right)$ of both actins as a function of protein concentration. By extrapolating, the intrinsic viscosity

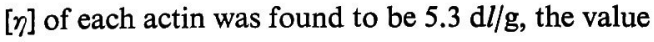
which is comparable to the value for rabbit actin..$^{28)}$

The amino acid compositions of both mackerel actins are shown in Table 1, along with those of cod ordinary ${ }^{80)}$ and rabbit fast ${ }^{27)}$ muscle actins. Mackerel actins, as a whole, resemble each other in amino acid composition, except that the dark 
Table 1. Amino acid compositions of mackerel dark and ordinary muscle actins in comparison with those of other actins (residues per $10^{5} \mathrm{~g}$ protein)

\begin{tabular}{|c|c|c|c|c|}
\hline & \multicolumn{2}{|c|}{ Mackerel } & \multirow{2}{*}{$\operatorname{Cod}^{30\rangle}$} & \multirow{2}{*}{ Rabbit ${ }^{* 1}$} \\
\hline & Dark & Ordinary & & \\
\hline Lys & 39 & 36 & 43 & 45 \\
\hline His & 15 & 13 & 20 & 19 \\
\hline $3-\mathrm{MeHis}^{* 2}$ & 2.4 & 2.6 & N.D. $* 3$ & 2.4 \\
\hline Arg & 38 & 34 & 41 & 43 \\
\hline Asp & 83 & 87 & 71 & 81 \\
\hline Thr & 59 & 61 & 56 & 65 \\
\hline Ser & 59 & 60 & 55 & 53 \\
\hline Glu & 97 & 106 & 89 & 93 \\
\hline Pro & 47 & 39 & 51 & 45 \\
\hline Gly & 66 & 70 & 65 & 67 \\
\hline Ala & 77 & 84 & 68 & 69 \\
\hline Cys $/ 2$ & 11 & 11 & 11 & 12 \\
\hline Val & 47 & 45 & 49 & 50 \\
\hline Met & 34 & 37 & 28 & 38 \\
\hline Ile & 63 & 59 & 57 & 72 \\
\hline Leu & 62 & 68 & 64 & 62 \\
\hline Туг & 38 & 41 & 32 & 38 \\
\hline Phe & 28 & 29 & 27 & 29 \\
\hline $\operatorname{Trp}$ & 5 & 7 & 8 & 10 \\
\hline Total & 870.4 & 889.6 & 835 & 893.4 \\
\hline $\begin{array}{ll}* 1 & \text { Recalculat } \\
* 2 & 3-\text { Methylh } \\
* 3 & \text { Not detern }\end{array}$ & $\begin{array}{l}\text { d from } c \\
\text { tidine. } \\
\text { ined. }\end{array}$ & ol & A. 27) & \\
\hline
\end{tabular}

muscle actin contains more proline and less glutamic acid and alanine than the ordinary muscle actin. Both mackerel actins are also similar to cod and rabbit ones, though mackerel actins are featured by lower basic amino acids and tryptophan contents and by higher acidic amino acids and alanine contents. 3-Methylhistidine was determined to be 2.4 and 2.6 moles $/ 10^{\circ} \mathrm{g}$ protein for mackerel dark and ordinary actins, respectively, or approximately 1 mole per mole of each actin (molecular weight 42,000). This result agrees with those for other actins. ${ }^{11,18,31,82)}$

Finally, thermostability was examined taking solubility as a parameter for both mackerel actins in G- and F-forms. As shown in Fig. 9, no precipitate appeared when both actins were heated in G-form. Both actins were, however, coagulated when heated in F-form: more than half the protein was denatured and coagulated on heating at $60^{\circ} \mathrm{C}$ for $10 \mathrm{~min}$. No significant differences were observed in their thermostability as in most of other physicochemical properties of both actins described above.

In mammals, primary structures of fast skeletal and cardiac muscle actins have been reported to differ from each other in N-terminal region. ${ }^{88,84}$ Similar differences are supposed to be present between mackerel dark and ordinary muscle actins as well.

\section{Acknowledgement}

This work was partly supported by a Grant-inAid from the Ministry of Education, Science and Culture.

\section{References}

1) Q. Bone: J. Mar. Biol. Ass. U. K., 46, 321-349 (1966).

2) K. Tsukamoto: Bull. Japan. Soc. Sci. Fish., 47, 573-575 (1981).

3) I. A. Johnston, N. Frearson, and G. Goldspink: Experientia, 28, 713-714 (1974).

4) I. A. Johnston and B. Tota: Comp. Biochem. Physiol., 49B, 367-373 (1974).

5) S. Watabe, J. Maruyama, and K. Hashimoto: Bull. Japan. Soc. Sci. Fish. (in press).

6) J. Gergely, D. Praqay, A. F. Scholz, and J. C. SEIDEL: in "Molecular Biology of Muscular Contraction" (ed. by H. KumaGAI), Igaku Shoin, Tokyo, 1965, pp. 149-159.

7) S. WATABE and K. HASHIMOTO: J. Biochem., 87, 1491-1499 (1980).

8) I. Syrov́y, A. Gaspar-Godfrom, and G. HamorR: Arch. Internat. Physio!. Biochim., 78, 919-934 (1970).

9) M. BÁRÁNY, K. BÁRÁNY, T. RECKARD, and A. VOLPE: Arch. Biochem. Biophys., 109, 185-191 (1965).

10) S. Watabe and K. Hashimoto: Bull. Japan. Soc. Sci. Fish., 43, 329-334 (1977).

11) M. BÁRÁNY, K. BÁRÁNY, and F. GUBA: Nature, 179, 818-819 (1957).

12) J. A. SPUDich and S. WATT: J. Biol. Chem., 246, 81-84 (1971).

13) M. K. Rees and M. Young: J. Biol. Chem., 242, 4449-4458 (1967).

14) K. MrHashI: Arch. Biochem. Biophys., 107, 441448 (1964).

15) K. Weber and M. Osborn: J. Biol. Chem., 244, 4406-4412 (1969).

16) S. MOORE: J. Biol. Chem., 238, 235-237 (1963).

17) B. Penke, R. Gerenczi, and K. Kovacs: Anal. Biochem., 60, 45-50 (1974).

18) P. Johnson, C. I. Harris, and S. V. Perry: Biochem. J., 105, 361-370 (1967).

19) T. TAGUCH, K. KIKUCH, M. TANAKA, and K. Suzukı: Bull. Japan. Soc. Sci. Fish., 45, 639642 (1979).

20) A. G. Gornall, C. S. Bardawill, and M. M. 
DAvio: J. Biol. Chem., 177, 751-766 (1949).

21) T. Tsuchiya, H. Suzuki, and J. J. Matsumoto: Bull. Japan. Soc. Sci. Fish., 43, 1233-1240 (1977).

22) J. J. ConNell: Biochem. J., 70, 81-91 (1958).

23) M. S. Lewis, K. Maruyama, W. R. Carroll, D. R. Kominz, and K. LAKI: Biochemistry, 2, 34-39 (1963).

24) M. KaTz and H. J. Hall: Circulation Res., 13, 187-198 (1963).

25) R. E. Stephens and R. W. Linck: J. Mol. Biol., 40, 497-501 (1969).

26) F. B. Preston and G. N. Graham: Biochem. J., 127, 75P-76P (1972).

27) J. H. Collins and M. Euizinga : J. Biol. Chem.,
250, 5915-5920 (1975).

28) J. W. Bremer, H. Busch, and L. C. Yeoman: Biochemistry, 20, 2013-2017 (1981).

29) N. Seki, M. Krtao, K. Konno, and K. ARAi: Bull. Japan. Soc. Sci. Fish., 39, 1211-1219 (1973).

30) J. J. CoNNELl: Biochem. J., 71, 83-86 (1959).

31) J. R. Dedman and B. G. Harris: Biochem. Biophys. Res. Commun., 65, 170-175 (1975).

32) T. Nakamura, M. Yamaguchi, and T. YanaGISAWA: J. Biochem., 85, 627-631 (1979).

33) J. VANDEKERCKHOVE and K. Weber: J. Mol. Biol., 126, 783-802 (1978).

34) J. VANDEKERCKHOVE and K. WEBER: Eur. $J$. Biochem., 113, 595-603 (1981). 